\title{
STRUKTUR EKONOMI RAPUH: PELAJARAN YANG DIDAPAT DARI BUMI DIPASENA - LAMPUNG
}

\section{FRAGILE ECONOMIC STRUCTURE: LESSON LEARNED FROM BUMI DIPASENA - LAMPUNG}

\author{
Adi Asmariadi Budi ${ }^{1}$, Dian Sera Fauzela ${ }^{2}$, Eka Adistia ${ }^{3}$ \\ ${ }^{1}$ Research and Development Agency of Lampung Province; Email: adi_asmariadi@sbm-itb.ac.id \\ ${ }^{2}$ Research and Development Agency of Lampung Province; Email: tamajunio@gmail.com \\ ${ }^{3}$ Research and Development Agency of Lampung Province; Email: ekaadistia@ gmail.com
}

Dikirim 24 September 2020, Direvisi 12 November 2020, Disetujui 24 November 2020

\begin{abstract}
Abstrak: Struktur ekonomi suatu wilayah merupakan gambaran aktivitas ekonomi di suatu daerah yang menjadi pilar dalam menyokong terjadinya pergerakan ekonomi wilayah. Produk Domestik Regional Bruto (PDRB) dapat menjadi salah satu indikator gambaran struktur ekonomi wilayah. Pada beberapa kasus, terdapat banyak kota yang akhirnya mati karena berhentinya aktivitas ekonomi di kota tersebut. Penelitian ini bertujuan untuk memahami proses runtuhnya struktur ekonomi suatu wilayah dalam suatu kasus, yang kemudian dari hasil pemahaman tersebut dibentuk sebuah pola kerapuhan struktur ekonomi. Pendekatan kualitatif digunakan untuk menggali ke dalam terhadap kasus ditinggalkannya suatu wilayah ekonomi. Wilayah Bumi Dipasena Lampung menjadi kasus utama dalam penelitian ini untuk mendapatkan pembelajaran atas kerapuhan struktur ekonomi. Penelitian terhadap kasus pada wilayah tersebut menghasilkan sebuah pola kerapuhan struktur ekonomi yang disebabkan oleh homogenitas struktur ekonomi. Pola tersebut membentuk alur bahwa struktur ekonomi yang homogen menyebabkan kerapuhan struktur ekonomi, dan kerapuhan struktur ekonomi menyebabkan terjadinya malapetaka ekonomi (catastrophic economic).
\end{abstract}

Kata kunci: struktur ekonomi, rapuh, Bumi Dipasena, malapetaka ekonomi.

Abstract: The regional economic structure is a representation of economic activity in a region that becomes a pillar in supporting economic activity in a region. Gross Regional Domestic Product (GRDP) can be an indicator in visualizing regional economic structure. In some cases, there many cities finally become a "ghost city" because of the stop of its economic activity. This research has a purpose to understanding the collapse of the economic structure process in a region in some cases, based on those understanding then a fragile economic structure framework was built. The qualitative approach was used to dig deeper into the cases of the abandoned region. Bumi Dipasena Lampung region was the main case in this research to get a lesson learned on fragile economic structure. The results of this research are creating a fragile economic structure framework which is caused by homogeneity economic structure. That framework creates a flow that homogenous economic structure causing a fragile economic structure, and a fragile economic structure causing catastrophic economic.

Keywords: economic structure, fragile, Bumi Dipasena, catastrophic economic.

\section{PENDAHULUAN}

Pembangunan ekonomi yang diharapkan mampu meningkatkan pendapatan masyarakat dan mengembangkan keberadaan kota yang dihuni, pada kenyataannya tidak semua berjalan sesuai dengan rencana. Pembangunan yang terus bergulir, seringkali mengandalkan berbagai potensi yang dimiliki oleh setiap wilayah. Potensi tertinggi yang dimiliki oleh setiap wilayah menjadi penopang pertumbuhan ekonomi wilayah tersebut dan pada akhirnya menjadi sektor unggulan yang diandalkan. Keberadaan sektor unggulan tersebut, memicu pertumbuhan ekonomi di suatu wilayah. Pertumbuhan ekonomi didefinisikan Todaro (2006) sebagai proses peningkatan output dari waktu ke waktu. Potensi andalan tersebut kemudian menjadi sebuah struktur ekonomi wilayah yang menjadi penopang keberlangsungan pergerakan ekonomi suatu wilayah. Sebagai contoh wilayah dengan dominasi sawah akan memiliki struktur ekonomi pada sektor pertanian sebagai pilar utamanya. Hal ini pada umumnya dapat 
tergambarkan dalam Produk Domestik Regional Bruto (PDRB) dari suatu wilayah tersebut. Indikator ini menjadi alat yang dapat digunakan untuk mengukur struktur ekonomi suatu wilayah.

Keberadaan pertumbuhan ekonomi menjadi indikator penting dalam mengukur keberhasilan suatu pembangunan. Dalam lingkungan yang dinamis, potensi setiap wilayah yang menjadi pendukung utama ekonomi dapat berubah dari satu bagian ke bagian yang lain. Hal ini akan memengaruhi struktur ekonomi wilayah tersebut. Saat ekonomi wilayah mampu bertahan pada perubahan struktur ekonomi yang terjadi, maka wilayah itu semakin maju dan berkembang. Di sisi lain, saat perubahan struktur ekonomi tidak mampu menopang ekonomi suatu wilayah maka akan bermunculan kota-kota mati yang akan ditinggalkan oleh penghuninya sebagai salah satu wujud dari kegagalan struktur ekonomi wilayah.

Penelitian ini bertujuan untuk memahami proses runtuhnya struktur ekonomi suatu wilayah dalam suatu kasus, yang kemudian dari hasil pemahaman tersebut dibentuk sebuah pola kerapuhan struktur ekonomi. Matinya beberapa kota di dunia terdapat banyak penyebab yang mendasarinya. Homogenitas struktur ekonomi menjadi preposisi sekaligus lingkup dalam pelaksanaan penelitian ini. Homogenitas membuat keragaman struktur ekonomi suatu wilayah menjadi rapuh karena ditopang hanya oleh satu pilar ekonomi tertentu. Penelitian ini membahas lebih dalam terkait homogenitas ekonomi tersebut melalui pendekatan kualitatif, sehingga diharapkan dapat menggali secara lebih dalam pola yang akan terjadi akibat adanya homogenitas struktur ekonomi wilayah.

\section{LANDASAN TEORI}

\section{A. Struktur Ekonomi Wilayah}

Pembangunan ekonomi didefinisikan sebagai proses yang menyebabkan pendapatan per kapita penduduk mengalami peningkatan dalam jangka panjang (Zakaria dkk, 2018). Sirojuzilam (2008) memberikan definisi pembangunan ekonomi sebagai suatu proses yang bersifat multidimensional, yang melibatkan perubahan besar, baik terhadap perubahan struktur ekonomi, perubahan sosial, mengurangi/menghapuskan kemiskinan, mengurangi ketimpangan, dan pengangguran dalam konteks pertumbuhan ekonomi. Sedangkan pembangunan ekonomi suatu daerah dapat didefinisikan sebagai suatu proses dimana pemerintah daerah dan masyarakat mengelola sumber daya yang dimiliki dan membentuk pola kemitraan antara pemerintah daerah dengan sektor swasta untuk menciptakan suatu lapangan kerja baru dan merangsang perkembangan kegiatan ekonomi dalam wilayah tersebut (Arsyad, 1999). Untuk dapat mewujudkan pembangunan ekonomi yang efisien, hal pertama yang harus dilakukan adalah perencanaan yang teliti mengenai penggunaan sumber daya yang dimiliki suatu wilayah.

Kemampuan mengukur tinggi rendahnya kemajuan pembangunan suatu negara dapat dinilai melalui dua indikator yaitu Produk Domestik Bruto (PDB) untuk ruang lingkup nasional dan Produk Domestik Regional Bruto (PDRB) untuk ruang lingkup regional. PDB didefinisikan sebagai nilai pasar barang dan jasa akhir yang diproduksi dalam perekonomian dalam kurun waktu tertentu. PDB sering di anggap sebagai ukuran terbaik dari kinerja perekonomian (Mankiw:2005). Selanjutnya PDRB menurut Rachman \& Chamelia (2015) memiliki pengertian sebagai jumlah nilai tambah yang dihasilkan untuk seluruh wilayah usaha dan jasa dalam suatu wilayah, penerapan jumlah seluruh nilai barang dan jasa akhir 
yang dihasilkan seluruh unit ekonomi. PDRB juga dapat didefinisikan sebagai jumlah nilai tambah yang dihasilkan oleh seluruh unit usaha atau merupakan jumlah seluruh nilai barang dan jasa oleh seluruh unit ekonomi disuatu wilayah.

Istilah PDRB merupakan gabungan dari empat kata. Pertama adalah produk yang berarti seluruh nilai produksi baik barang maupun jasa. Kedua adalah domestik yang berarti perhitungan nilai produksi yang dihasilkan hanya oleh faktor-faktor produksi yang berada dalam wilayah domestik tanpa melihat apakah faktor produksi tersebut dikuasai oleh penduduk atau bukan. Ketiga adalah regional yang berarti perhitungan nilai produksi yang dihasilkan hanya oleh penduduk tanpa memperhatikan apakah faktor produksi yang digunakan berada dalam wilayah domestik atau bukan. Bagian terakhir adalah bruto yang bermakna perhitungan nilai produksi kotor karena masih mengandung biaya penyusutan (Saberan, 2002).

\section{B. Aktivitas dan Pertumbuhan Ekonomi}

Pertumbuhan ekonomi merupakan suatu proses peningkatan output dari waktu ke waktu. Keberadaan pertumbuhan ekonomi menjadi indikator penting dalam mengukur keberhasilan suatu pembangunan (Todaro : 2006). Sedangkan menurut Untoro (2010) pertumbuhan ekonomi merupakan perkembangan kegiatan dalam perekonomian yang menyebabkan barang dan jasa yang diproduksi dalam masyarakat bertambah dan kesejahteraan masyarakat meningkat dalam jangka panjang.

Pada perkembangannya, terdapat beberapa teori yang menganalisa penyebab pertumbuhan ekonomi dan faktor-faktor yang menentukan pertumbuhan ekonomi:

\section{(1). Teori pertumbuhan klasik}

Keberadaan teori ini dipelopori oleh Adam Smith, David Ricardo, Malthus dan John Stuart Mill. Menurut teori ini pertumbuhan ekonomi dipengaruhi oleh empat faktor yaitu jumlah penduduk, jumlah barang modal, luas tanah, dan kekayaan alam serta teknologi yang digunakan. Teori ini menyoroti masalah pengaruh pertambahan penduduk terhadap pertumbuhan ekonomi.

\section{(2). Teori pertumbuhan neo klasik}

Keberadaan teori ini dipelopori oleh Robert Solow, Edmund Phelps, Harry Johnson dan J.E. Meade. Menurut teori ini pertumbuhan ekonomi tergantung pada pertambahan dan penawaran faktor-faktor produksi dan tingkat kemajuan teknologi.

\section{(3). Teori pertumbuhan Harrold-Domar}

Teori pertumbuhan ini merupakan perkembangan dari teori pertumbuhan makro John Maynard Keynes. Menurut teori ini, setiap perekonomian pada dasarnya harus mencadangkan atau menabung sebagian dari pendapatan nasionalnya untuk menambah atau menggantikan barang-barang modal. Untuk memacu proses pertumbuhan ekonomi, dibutuhkan investasi baru yang merupakan tambahan netto terhadap cadangan atau stok modal (capital stock).

\section{(4). Teori Schumpeter}

Teori ini menekankan pada inovasi yang dilakukan oleh para pengusaha dan menekankan bahwa kemajuan teknologi sangat penting.

\section{METODOLOGI}

Pendekatan kualitatif dilakukan untuk memperoleh hasil yang akurat dan mendalam dalam judul penelitian "Struktur Ekonomi Rapuh : Pelajaran yang didapat dari Bumi Dipasena" ini. Metode penelusuran fakta dan sejarah melalui beberapa media dan berita dilakukan dalam upaya menggali data primer dalam penelitian ini.

\subsection{Jenis Penelitian}

Penelitian ini adalah jenis penelitian kualitatif. Menurut Bogdan dan Biklen (1992) penelitian kualitatif adalah salah satu prosedur penelitian yang 
menghasilkan data deskriptif berupa ucapan atau tulisan dan perilaku orangorang yang diamati. Pendekatan kualitatif diharapkan mampu menghasilkan uraian yang mendalam tentang ucapan, tulisan, dan/atau perilaku yang dapat diamati dari suatu individu, kelompok, masyarakat, dan/atau organisasi tertentu dalam suatu konteks tertentu yang dikaji dari sudut pandang yang utuh, komprehensif, dan holistik. Penelitian kualitatif memiliki tujuan untuk mendapatkan pemahaman yang sifatnya umum terhadap kenyataan sosial dan perspektif partisipan. Pemahaman ini diperoleh melalui tahapan analisa terhadap kenyataan sosial yang menjadi fokus penelitian. Studi deskriptif dilakukan dengan tujuan untuk mendapatkan deskripsi akurat dari manusia, kejadian ataupun situasi (Saunders \& Lewis, 2012). Jenis penelitian kualitatif deskriptif didefinisikan sebagai metode yang dapat digunakan untuk memahami kejadian harian dari suatu sampel riset yang di analisis (Magilvy \& Thomas, 2009).

\subsection{Sumber Data}

Menurut Arikunto (2002) penelitian kualitatif memiliki sumber data utama yang bersumber dari kata-kata dan tindakan, selebihnya adalah data tambahan yang bersumber dari dokumen dan lainlain. Pada penelitian ini sumber data berasal dari berita media yang ada mengenai Bumi Dipasena.

\section{HASIL DAN PEMBAHASAN}

Penelusuran data yang didapatkan menghasilkan beberapa hal yang menjadi analisis pembahasan dalam penelitian ini, yaitu struktur ekonomi wilayah dan kondisi ekonomi perusahaan. Struktur ekonomi berkaitan dengan perubahan hingga keruntuhan struktur yang berdampak pada kondisi wilayah. Sedangkan kondisi ekonomi perusahaan berkaitan dengan perusahaan dalam perannya membangun ekonomi ataupun sebaliknya dalam menghancurkan ekonomi wilayah. Beberapa poin pembahasan berikut dipaparkan bagaimana kedua kondisi tersebut berlangsung melalui beberapa kasus.

\section{A. Perubahan Struktur Ekonomi: Studi \\ Kasus Kabupaten Karawang}

Kabupaten Karawang merupakan salah satu sentra pertanian di Provinsi Jawa Barazt. Keberadaan kabupaten ini dikenal sebagai lumbung padi nasional. Pembangunan sektor pertanian telah memberikan sumbangan besar pada pembangunan nasional, baik sumbangan langsung seperti dalam pembentukan PDB dan penyerapan tenaga kerja. Di sisi lain, perkembangan Kabupaten Karawang sebagai salah satu kawasan strategis ekonomi mengakibatkan permintaan lahan meningkat dan berpengaruh terhadap jumlah sawah yang ada. Jumlah sawah di Kabupaten Karawang cenderung berkurang seiring dengan berkembangnya sektor industri di daerah sekitarnya. Kawasan di sekitar Kabupaten Karawang yaitu kawasan Bodetabek (Bogor, Depok, Tangerang dan Bekasi) yang telah berkembang menjadi kawasan penyangga ibukota, memberikan dampak pada Kabupaten Karawang. Selanjutnya, kemudahan akses yang dilalui oleh jalur Pantura serta letak geografis yang berada di dua kota besar yaitu Jakarta dan Bandung mengakibatkan daerah ini menjadi daerah penyangga yang strategis untuk menjadi salah satu pusat perekonomian yang menyebabkan sektorsektor ekonomi pun mulai tumbuh (Chofyan dkk, 2016).

Perkembangan Kabupaten Karawang menjadi kawasan strategis ekonomi dan diiringi dengan peningkatan jumlah penduduk, mengakibatkan permintaan lahan juga meningkat dan berpengaruh pada alih fungsi keberadaan lahan sawah yang ada. Keadaan ini pada akhirnya berdampak pada perubahan struktur ekonomi di Kabupaten Karawang. Perubahan struktur ekonomi ini terjadi melalui pergeseran peranan sektor 
pertanian menuju sektor industri. Walaupun secara absolut sektor pertanian telah mengalami pertumbuhan yang cukup tinggi, namun secara relatif sektor pertanian mengalami penurunan sejalan dengan pertumbuhan sektor industri. Hal ini menunjukkan semakin mengecilnya kontribusi sektor pertanian dalam struktur ekonomi nasional (Chofyan dkk, 2016).

Industrialisasi merupakan proses yang terjadi di Kabupaten Karawang. Industrialisasi didefinisikan sebagai suatu proses perubahan sosial ekonomi yang mengubah sistem pencaharian masyarakat agraris menjadi masyarakat industri (Ardi, 2016). Pada proses industrialisasi terjadi interaksi antara perkembangan teknologi, inovasi, spesialisasi, dan perdagangan dunia untuk meningkatkan pendapatan masyarakat dengan mendorong perubahan struktur ekonomi. Perubahan sektor industri yang pesat beberapa tahun terakhir, pada akhirnya telah menggeser peranan sektor pertanian dalam struktur perekonomian.

Berdasarkan Keputusan Presiden Republik Indonesia Nomor 53 Tahun 1989 tentang Pengembangan Kawasan Industri, Kabupaten Karawang telah ditetapkan menjadi daerah pengembangan kawasan industri. Sehingga dapat dikatakan bahwa struktur perekonomian Kabupaten Karawang bercorak industrialisasi. indikasi didasarkan karena sektor industri pengolahan mendominasi struktur perekonomian Kabupaten Karawang. Berdasarkan data Badan Pusat Statistik (BPS), Struktur ekonomi Kabupaten Kawarang menurut lapangan usaha, sektor industri pengolahan dari tahun 2009-2013 memiliki nilai rata-rata sebesar $53 \%$, sedangkan sektor pertanian hanya sebesar $8,44 \%$.

\section{B. Kegagalan Ekonomi: Kasus Mobil Nasional}

Sebagai upaya mendukung kemandirian bangsa melalui penyediaan sarana transportasi darat, maka diwujudkan dalam bentuk pembuatan mobil nasional. Untuk merintis pembangunan mobil nasional maka pemerintah mengeluarkan Instruksi Presiden Republik Indonesia Nomor 2 tahun 1996 tentang Program Mobil Nasional, yang menunjuk PT Timor Putra Nusantra (TPN) sebagai pionir yang memproduksi mobil nasonal. Karena belum dapat memproduksi di dalam negeri, maka keluarlah Keputusan Presiden Republik Indonesia Nomor 42 tahun 1996 yang membolehkan PT TPN mengimpor mobil nasional yang kemudian diberi merek "Timor" dalam bentuk jadi atau completely build-up(CBU) dari Korea Selatan.

Selain itu, PT TPN diberikan hak istimewa, yaitu bebas pajak barang mewah dan bebas bea masuk barang impor. Hak itu diberikan kepada PT TPN dengan syarat menggunakan kandungan lokal hingga 60 persen dalam tiga tahun sejak mobnas pertama dibuat. Namun bila penggunaan kandungan lokal yang ditentukan secara bertahap yakni 20 persen pada tahun pertama dan 60 persen pada tahun ketiga tidak terpenuhi, maka PT TPN harus menanggung beban pajak barang mewah dan bea masuk barang impor. Namun, soal kandungan lokal ini agaknya diabaikan selama ini, karena Timor masuk ke Indonesia dalam bentuk jadi dari Korea Selatan, dan tanpa bea masuk apapun, termasuk biaya pelabuhan dan lainnya.

Kehadiran industri mobil nasional ini memicu kontroversi mengingat industri mobil nasional telah dianakemaskan oleh pemerintah melalui pembebasan tarif masuk barang impor dan perlakuan bebas pajak barang mewah. Akibatnya, Jepang sebagai salah satu produsen mobil di dunia melakukan protes terhadap Organisasi Perdagangan Dunia (WTO), mengingat hal tersebut melanggar kesepakatan perdagangan internasional. 
C. Matinya sebuah kota

Gagalnya sebuah kota berdampak pula terhadap berhentinya aktivitas ekonomi di wilayah tersebut. Sebagaimana diketahui bahwa pertumbuhan ekonomi suatu wilayah ditimbulkan karena adanya aktivitas ekonomi. Peningkatan nilai pasar suatu barang dan jasa yang diproduksi di suatu wilayah menyebabkan ekonomi bertumbuh (Agarwal, 2017). Produk Domestik Regional Bruto (PDRB) menjadi indikator pengukuran terhadap pertumbuhan ekonomi suatu wilayah. Aktivitas ekonomi hidup karena adanya pertumbuhan ekonomi, beberapa faktor yang menjadi komponen pertumbuhan ekonomi diantaranya adalah adanya sumber daya alam, infrastruktur, populasi atau tenaga kerja, sumber daya manusia, teknologi, dan regulasi (Agarwal, 2017).

Tabel 1.Penyebab suatu kota/wilayah ditinggalkan atau tak dihuni

\begin{tabular}{|c|c|c|}
\hline No & Nama Kota & Sebab ditinggalkan \\
\hline 1. & $\begin{array}{l}\text { Pulau } \\
\text { Hashima, } \\
\text { Jepang }\end{array}$ & $\begin{array}{l}\text { Bekas } \\
\text { pertambangan } \\
\text { batubara }\end{array}$ \\
\hline 2. & $\begin{array}{l}\text { Bodie, } \\
\text { California }\end{array}$ & $\begin{array}{l}\text { Bekas } \\
\text { pertambangan } \\
\text { emas }\end{array}$ \\
\hline 3. & $\begin{array}{l}\text { Humberstone } \\
\text {, Chile }\end{array}$ & $\begin{array}{l}\text { Bekas } \\
\text { pertambangan } \\
\text { potasium nitrat }\end{array}$ \\
\hline 4. & $\begin{array}{l}\text { Cody, British } \\
\text { Columbia }\end{array}$ & $\begin{array}{l}\text { Bekas } \\
\text { pertambangan } \\
\text { mineral }\end{array}$ \\
\hline 5 . & $\begin{array}{l}\text { Ruby, } \\
\text { Arizona }\end{array}$ & $\begin{array}{l}\text { Bekas } \\
\text { pertambangan }\end{array}$ \\
\hline 6. & $\begin{array}{l}\text { Kolmanskop, } \\
\text { Namibia }\end{array}$ & $\begin{array}{l}\text { Bekas } \\
\text { pertambangan } \\
\text { berlian }\end{array}$ \\
\hline 7. & $\begin{array}{l}\text { Kennecott, } \\
\text { Alaska }\end{array}$ & $\begin{array}{l}\text { Bekas } \\
\text { pertambangan }\end{array}$ \\
\hline 8. & $\begin{array}{l}\text { Wittenoom, } \\
\text { Western } \\
\text { Australia }\end{array}$ & $\begin{array}{l}\text { Bekas } \\
\text { pertambangan } \\
\text { asbestos }\end{array}$ \\
\hline 9. & $\begin{array}{l}\text { Virginia City } \\
\text { dan Nevada } \\
\text { City, } \\
\text { Montana }\end{array}$ & $\begin{array}{l}\text { Bekas } \\
\text { pertambangan }\end{array}$ \\
\hline
\end{tabular}

\begin{tabular}{|c|c|c|}
\hline 10. & $\begin{array}{l}\text { Bannack, } \\
\text { Montana }\end{array}$ & $\begin{array}{l}\text { Bekas } \\
\text { pertambangan } \\
\text { emas }\end{array}$ \\
\hline 11. & $\begin{array}{l}\text { Centralia, } \\
\text { Pennsylvania }\end{array}$ & $\begin{array}{l}\text { Bencana } \\
\text { pertambangan } \\
\text { batubara }\end{array}$ \\
\hline 12. & $\begin{array}{l}\text { Kadykchan, } \\
\text { Russia }\end{array}$ & $\begin{array}{l}\text { Bencana } \\
\text { pertambangan }\end{array}$ \\
\hline 13. & Craco, Italia & $\begin{array}{l}\text { Terjadinya bencana } \\
\text { alam }\end{array}$ \\
\hline 14. & $\begin{array}{l}\text { Balestrino, } \\
\text { Italia }\end{array}$ & $\begin{array}{l}\text { Terjadinya bencana } \\
\text { alam }\end{array}$ \\
\hline 15. & $\begin{array}{l}\text { Plymouth, } \\
\text { Montserrat }\end{array}$ & $\begin{array}{l}\text { Peristiwa bencana } \\
\text { alam }\end{array}$ \\
\hline 16. & $\begin{array}{l}\text { Cahawba, } \\
\text { Alabama }\end{array}$ & Bencana alam \\
\hline 17. & $\begin{array}{l}\text { Pripyat, } \\
\text { Ukraina }\end{array}$ & Bencana nuklir \\
\hline 18. & $\begin{array}{l}\text { Pulau North } \\
\text { Brother, New } \\
\text { York }\end{array}$ & Bencana penyakit \\
\hline 19. & $\begin{array}{l}\text { Oradour-sur- } \\
\text { Glane, } \\
\text { Prancis } \\
\end{array}$ & Peristiwa perang \\
\hline 20. & $\begin{array}{l}\text { Tawergha, } \\
\text { Libya }\end{array}$ & Peristiwa perang \\
\hline 21. & $\begin{array}{l}\text { Kayaköy, } \\
\text { Turki }\end{array}$ & Peristiwa perang \\
\hline 22. & $\begin{array}{l}\text { Agdam, } \\
\text { Azerbaijan }\end{array}$ & Peristiwa perang \\
\hline 23. & $\begin{array}{l}\text { Döllersheim, } \\
\text { Austria }\end{array}$ & Peristiwa perang \\
\hline 24. & $\begin{array}{l}\text { Varosha, } \\
\text { Cyprus }\end{array}$ & $\begin{array}{l}\text { Wilayah sengketa } \\
\text { antar negara }\end{array}$ \\
\hline 25. & $\begin{array}{l}\text { Copehill } \\
\text { Down, } \\
\text { Inggris } \\
\end{array}$ & $\begin{array}{l}\text { Bekas fasilitas } \\
\text { militer }\end{array}$ \\
\hline 26. & $\begin{array}{l}\text { Tianducheng, } \\
\text { China }\end{array}$ & $\begin{array}{l}\text { Kegagalan } \\
\text { perencanaan } \\
\text { pembangunan } \\
\end{array}$ \\
\hline 27. & $\begin{array}{l}\text { Seseña, } \\
\text { Spanyol }\end{array}$ & $\begin{array}{l}\text { Kegagalan } \\
\text { perencanaan/ } \\
\text { pengembangan }\end{array}$ \\
\hline 28. & $\begin{array}{l}\text { Kilamba New } \\
\text { City, Angola }\end{array}$ & $\begin{array}{l}\text { Kegagalan } \\
\text { perencanaan/ } \\
\text { pengembangan }\end{array}$ \\
\hline 29. & $\begin{array}{l}\text { Texola, } \\
\text { Oklahoma }\end{array}$ & $\begin{array}{l}\text { Penurunan } \\
\text { produksi komoditas }\end{array}$ \\
\hline 30. & Mandu, India & Kota kuno (sejarah) \\
\hline
\end{tabular}




\begin{tabular}{|l|l|l|}
\hline 31. & $\begin{array}{l}\text { Al'Ula, Saudi } \\
\text { Arabia }\end{array}$ & Kota kuno (sejarah) \\
\hline 32. & $\begin{array}{l}\text { Fordlandia, } \\
\text { Brasil }\end{array}$ & $\begin{array}{l}\text { Hama penyakit } \\
\text { tanaman dan } \\
\text { kebijakan } \\
\text { pemerintah yang } \\
\text { kaku }\end{array}$ \\
\hline 33. & $\begin{array}{l}\text { Glenrio, New } \\
\text { Mexico }\end{array}$ & $\begin{array}{l}\text { Persaingan dengan } \\
\text { kota lain }\end{array}$ \\
\hline 34. & $\begin{array}{l}\text { Pulang } \\
\text { Galang, } \\
\text { Batam }\end{array}$ & $\begin{array}{l}\text { Bekas pengungsian } \\
\text { Vietnam }\end{array}$ \\
\hline
\end{tabular}

Sumber: (5 Old and Abandoned Mining Towns, 2020; Aisyah, 2020; Andrews, 2015; Hansen, 2018)

Tabel 1 memperlihatkan terhentinya aktivitas ekonomi di suatu kota/wilayah. Hasil penelusuran tersebut terpampang beragam penyebab terhentinya aktivitas ekonomi suatu wilayah. Secara umum matinya sebuah kota disebabkan oleh telah habisnya komoditas tambang di wilayah tersebut, beberapa hal lain disebabkan karena adanya bencana, peristiwa perang, sengketa wilayah, kegagalan perencanaan pembangunan, dll. Habisnya komoditas pertambangan bersesuaian dengan komponen pertumbuhan ekonomi, yaitu faktor sumber daya alam. Hal itu berkaitan erat dengan unsur barang dan jasa yang diproduksi oleh sebuah wilayah. Yang terjadi pada kasus matinya kota-kota berbasis pertambangan tersebut adalah karena tidak adanya lagi produksi barang dan jasa yang berupa komoditas pertambangan.

\section{Belajar dari Runtuhnya Ekonomi Wilayah Bumi Dipasena}

Bumi Dipasena sebagai kompleks pertambakan udang yang berada di wilayah Pesisir Timur Lampung dan Sumatera Selatan merupakan eksportir udang terbesar di dunia pada masanya (Benarkah Bumi Dipasena Hanya Kolam Kosong dan Air Belaka, 2018). Dimulai pada tahun 1985, produksi udang dari Bumi Dipasena pernah mencapai hingga
2.000 ton/bulan. Pada durasi waktu tahun 1995 sampai 1996 bahkan pernah mengekspor hingga 25.000 ton/tahun. Kawasan pertambakan udang Bumi Dipasena mencapai seluas 24.000 hektar yang berada di Kecamatan Rawajitu Timur Kabupaten Tulang Bawang. Kawasan tersebut merupakan bagian inti dari kawasan terpadu seluas 98.000 hektar. Kawasan pertambakan Bumi Dipasena telah dilengkapi dengan fasilitas-fasilitas utama dan pendukung pertambakan seperti jaringan kanal, pembangkit listrik, pabrik pakan, kolam penelitian, hatchery benur, dll. Kawasan terpadu tersebut membentuk sebuah kota mandiri yang berpenduduk hingga 100.000 jiwa.

Pengembangan pertambakan udang Bumi Dipasena pada mulanya dilakukan oleh PT. Dipasena Citra Darmaja (selanjutnya disebut Dipasena) yang dimiliki oleh Sjamsul Nursalim (Setyawan, 2017). Kemudian karena beberapa hal, kepemilikan Dipasena beralih ke PT Aruna Wijaya Sakti (PT AWS) (Dipasena Riwayatmu Kini, 2014). Kini wilayah tersebut telah menjadi kota "hantu" dengan gubuk-gubuk yang telah ditinggalkan dan dikelilingi semak belukar dan ilalang (Dari Titik Nol Dipasena, 2017).

Terdapat beberapa faktor yang menyebabkan hancurnya pertambakan udang Bumi Dipasena yang dirunutkan sebagai berikut:

\section{Kasus korupsi pemilik perusahaan}

Berawal dari krisis moneter yang menerpa Indonesia di tahun 1998, perbankan nasional ikut terdampak dan mengalami guncangan. Pemerintah pada akhirnya membentuk Badan Penyehatan Perbankan Nasional (BPPN) untuk mengatasi kondisi tersebut melalui Keputusan Presiden Nomor 34 Tahun 1998. Dampak dari proses penyehatan perbankan tersebut ternyata menyeret Sjamsul Nursalim pada tahun 2000 dalam jeratan kasus korupsi Bantuan Likuiditas Bank Indonesia (BLBI) (Dipasena 
Riwayatmu Kini, 2014). Syafruddin Arsyad Temenggung sebagai kepala BPPN pada kala itu ikut menjadi terdakwa dalam kasus tindak pidana korupsi terkait dengan Dipasena (Gabrillin, 2018).

Aset Dipasena diserahkan kepada Badan Penyehatan Perbankan Nasional (BPPN) sebagai akibat dari pelunasan kewajiban yang pada saat itu Sjamsul Nursalim selaku obligor penerima Bantuan Likuiditas Bank Indonesia (BLBI) (Setyawan, 2017). Total aset Dipasena pada saat itu mencapai hingga Rp. 4,8 triliun, yang merupakan nilai yang harus dilunasi Sjamsul Nursalim kepada BPPN. Namun berdasar pada penyelidikan Komisi Pemberantasan Korupsi (KPK), masih terdapat tagihan sebesar Rp. 3,7 triliun yang belum dibayarkan.

2. Wanprestasi perjanjian kerja sama antara perusahaan dengan mitra kerja

Dipasena menjalankan usahanya melalui pola kemitraan dengan para petambak udang (Dipasena Riwayatmu Kini, 2014). Pola tersebut terbukti dapat menarik para petambak yang tidak hanya berasal dari daerah Lampung, namun juga berasal dari berbagai daerah di Indonesia untuk datang sebagai petambak di Bumi Dipasena. Lahan seluas 2000 meter persegi dan sebuah rumah sederhana didapatkan oleh masing-masing petambak dengan total nilai sebesar Rp. 165 juta yang kemudian tertanggung sebagai hutang yang dibebankan kepada para petambak. Menurut salah seorang petambak, Dipasena menawarkan perjanjian kerja sama dengan para petambak (Gabrillin, 2018). Mekanisme kerja sama yang ditawarkan dengan melalui pemberian kredit untuk modal kerja Rp. 135 juta yang dapat dilunasi setelah bekerja selama beberapa tahun, dan juga pemberian janji kepemilikan tambak. Dipasena menerapkan pemotongan 20\% dari hasil panen sebagai sistem pelunasan hutang para petambak atas modal dan fasilitas yang telah diberikan (Dipasena Riwayatmu Kini, 2014). Namun yang menjadi masalah, para petambak hanya diminta menandatangani dan tidak diperkenankan untuk membaca isi dari surat perjanjian kerja sama tersebut (Gabrillin, 2018). Dipasena hanya memberikan investasi perlengkapan budidaya dan modal kerja secara bertahap. Dari sini awal mula permasalahan tersebut terjadi, para petambak harus menyerahkan seluruh hasil tambak kepada Dipasena tanpa menerima uang, dimana pembayaran hanya berupa dokumen kertas yang diterima oleh petambak. Selain itu, petambak tidak pernah diinformasikan mengenai status dan posisi hutang mereka.

Selain pada era kepemilikan Sjamsul Nursalim, pada era pengelolaan tambak oleh PT AWS, juga terjadi adanya wanprestasi dalam bentuk belum dibayarkannya sisa hasil usaha (SHU) sebesar Rp. 38 miliar kepada petambak (Dipasena Riwayatmu Kini, 2014).

3. Konflik antara perusahaan dengan mitra kerja

Adanya pengakuan pemerasan yang dilakukan oleh Dipasena kepada para petambak. Dalam kasus hutang sebagai akibat dari adanya kemitraan antara Dipasena dengan para petambak, intimidasi dari Dipasena banyak dirasakan oleh petambak pada saat petambak menanyakan posisi hutang mereka (Gabrillin, 2018).

Posisi hutang tersebut berlanjut hingga era pengelolaan tambak oleh PT AWS. Akibat ketidaktransparanan pengelolaan hutang tersebut pada akhirnya bergulir hingga ke meja hijau. PT AWS menggugat 400 petambak melalui Pengadilan Negeri Menggala, namun kalah. Kemudian PT AWS melakukan banding ke Pengadilan Tinggi Lampung(Dipasena Riwayatmu Kini, 2014). Namun yang terjadi selanjutnya adalah di tahun 2014, Pengadilan Tinggi Lampung mengabulkan gugatan Dipasena yang menyatakan bahwa 400 petambak memiliki hutang sebesar Rp. 165 juta kepada Dipasena (Dipasena 
Riwayatmu Kini, 2014). Padahal para petambak merasa sudah melunasi hutang tersebut melalui cicilan sebesar $20 \%$ dari hasil panen yang telah berlangsung selama 8 tahun. Dampak dari dikabulkannya gugatan tersebut adalah diambilalihnya aset milik petambak oleh PT AWS.

4. Lemahnya peran pemerintah dalam penyelesaian konflik

Konflik yang terjadi antara para petambak dengan Dipasena di masa kepemilikan Sjamsul Nursalim ternyata tidak berhenti setelah ia terjerat kasus korupsi di tahun 2000. Pada tahun 2004 seluruh aset Dipasena disita oleh BPPN dan diserahkan kepada PT Perusahaan Pengelola Aset Negara (PT PPA) (Dipasena Riwayatmu Kini, 2014). Pada bulan September 2004, melalui amanat Dewan Perwakilan Rakyat (DPR), Dipasena masuk ke dalam program revitalisasi. Pemerintah pada saat itu juga mendukung program revitalisasi Dipasena. Kemudian di tahun 2007, PT PPA menjual aset kredit dan saham Dipasena kepada PT Central Proteina Prima (CPP group) yang kemudian pengelolaannya dilakukan oleh PT Aruna Wijaya Sakti (PT AWS). Penjualan ini sangat kontroversial karena hanya dijual sebesar Rp. 688 miliar dari nilainya sebesar Rp. 2,388 triliun.

Amanat revitalisasi yang dicanangkan selama 12 bulan ternyata tidak berjalan lancar, PT AWS mangkir dari kewajibannya (Dipasena Riwayatmu Kini, 2014). Banyak masalah yang terjadi, yang kemudian memuncak pada 11 Januari 2011 dimana para petambak mendeklarasikan untuk memutuskan hubungan kemitraan dengan PT AWS. Hal ini menyebabkan pemerintah melalui Kementerian Kelautan dan Perikanan membentuk tim untuk mengevaluasi kerja sama antara PT AWS dengan petambak, yang kemudian menghasilkan temuan bahwa PT AWS tidak mampu menjalankan kewajibannya kepada petambak. Bahkan PT AWS juga melakukan perlawanan dengan memutus pasokan listrik ke wilayah Bumi Dipasena. Pemerintah kemudian membentuk tim terpadu untuk memediasi antara perusahaan dengan petambak plasma. Namun mediasi tersebut tidak menemukan titik temu, bahkan pihak perusahaan terus berusaha untuk melawan dengan beragam tindakan yang dilakukannya.

\section{E. Fordlandia: Sebuah Sandingan}

Sebagai kasus perbandingan matinya sebuah kota adalah kasus kota Fordlandia. Nama Kota Fordlandia diambil dari nama sang pendiri yaitu Henry Ford. Henry Ford sebagai seorang pembuat mobil dan industrialis, berusaha membangun Kota Fordlandia sebagai upaya untuk menciptakan sumber independen karet ban untuk kendaraannya agar bebas dari monopoli manufaktur.

Ford kemudian membeli petak besar tanah di Amazon, lalu mulai membangun sebuah kota bergaya Amerika yang aneh di hutan. Kota Fordlândia berada di tepi timur sungai Tapajos, kota ini dapat dicapai dengan perahu melalui Itaituba dan Santarém di negara bagian Para, di Utara Brasil. Ia juga membangun lapangan golf, perpustakaan, rumah sakit, serta toko-toko dan restoran untuk membuat para karyawan yang pindah bahagia (www.cnnindonesia.com).

Henry Ford membangun Kota Fordlandia dengan segenap aturan-aturan yang telah ia tetapkan. Salah satu aturan tersebut berupa diet makanan dan aturan mempelajari tari tradisional. Henry Ford melupakan bahwasanya manusia adalah makhluk sosial. Sehingga pada akhirnya, kerusuhan dan pemberontakan terjadi (www.vice.com). Kerusuhan dan pemberontakan berujung pada kegagalan besar. Hal ini menyisakan bangunanbangunan yang tidak digunakan. 


\section{SIMPULAN DAN SARAN}

Poin-poin dalam Bab pembahasan menghasilkan beberapa temuan menarik terkait dengan tema kerapuhan struktur ekonomi wilayah. Beberapa hal tersebut dapat disimpulkan sebagai berikut:

1. Perubahan atau transformasi struktur ekonomi suatu wilayah tidak menyebabkan struktur ekonomi suatu wilayah menjadi rapuh.

2. Kegagalan ekonomi sebuah perusahaan yang berada di wilayah dengan struktur ekonomi yang heterogen (lebih dari satu pilar struktur ekonomi) dan memiliki kompetitor tidak menyebabkan struktur ekonomi suatu wilayah menjadi rapuh.

3. Suatu wilayah dengan struktur ekonomi yang homogen (hanya satu jenis struktur ekonomi sebagai penopang) memiliki kerapuhan dalam struktur ekonominya.

4. Struktur ekonomi yang rapuh menyebabkan malapetaka ekonomi (economic catastrophic) yaitu berupa matinya sebuah wilayah/kota karena terhentinya aktivitas ekonomi.

Berdasarkan pada simpulan tersebut, maka dapat dibangun pola (framework) terjadinya kerapuhan struktur ekonomi dalam gambaran berikut ini:

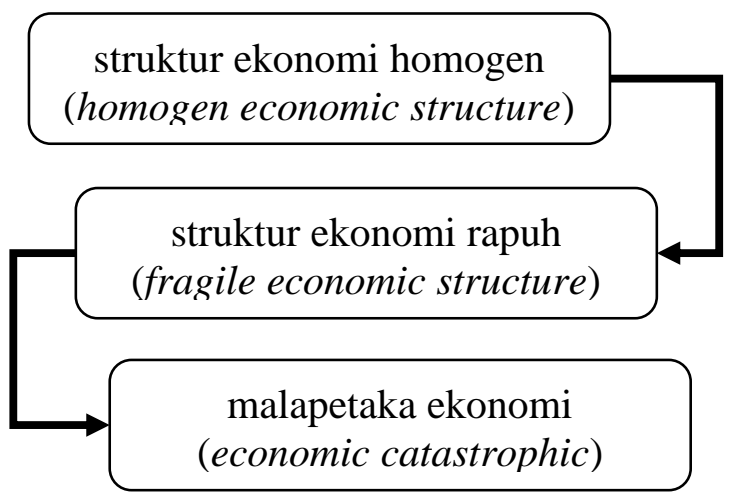

Gambar 1. Pola kerapuhan struktur ekonomi

Pola atau framework tersebut menggambarkan bahwa struktur ekonomi wilayah yang homogen, yaitu hanya ditopang oleh satu jenis lapangan usaha atau komoditas, akan menyebabkan kerapuhan struktur ekonomi. Kemudian apabila terdapat peristiwa yang menyerang struktur ekonomi yang rapuh tersebut, maka kehancuran ekonomi suatu wilayah dapat terjadi. Pada akhirnya sebuah wilayah akan ditinggalkan karena tidak adanya aktivitas ekonomi yang terjadi.

Pembelajaran yang didapat melalui penelitian ini dapat berguna dalam perencanaan pembangunan suatu wilayah. Pemerintah dapat lebih berperan dalam mengatur struktur ekonomi suatu wilayah agar malapetaka ekonomi dapat dihindari dengan menghindari homogenitas struktur ekonomi wilayah.

\section{UCAPAN TERIMA KASIH}

Terima kasih diucapkan kepada seluruh tim dalam penelitian ini sehingga penelitian ini dapat terselesaikan dengan baik, dan juga pada Badan Penelitian dan Pengembangan Daerah Provinsi Lampung yang telah menaungi kami dalam melaksanakan riset ini. Ucapan khusus kepada anggota tim kami, Dian Sera Fauzela dan keluarga yang saat ini sedang berjuang untuk meraih harapannya, semoga segera terwujud. Amin.

\section{DAFTAR PUSTAKA}

5 Old and Abandoned Mining Towns. (2020). General Kinematics. https://www.generalkinematics.com/b log/5-old-abandoned-mining-towns/

Agarwal, P. (2017). Economic Growth Factors. Intelligent Economist. https://www.intelligenteconomist.co $\mathrm{m} /$ economic-growth/

Aisyah, Y. (2020). Sejarah Pulau Galang di Batam, Eks Tempat Pengungsian Vietnam. 
https://travel.kompas.com/read/2020/

03/23/230449327/sejarah-pulaugalang-di-batam-eks-tempat-

pengungsian-vietnam?page $=$ all

Andrews, E. (2015). 6 Famous Ghost Towns and Abandoned Cities. HISTORY.

https://www.history.com/news/6-

famous-ghost-towns-and-abandonedcities

Ardi, D.N. (2016). Analisis Struktur Ekonomi dan Sektor Basis dalam Mendorong Perekonomian Kabupaten Karawang Periode 20092013.Skripsi. Fakultas Ekonomi. Universitas Diponegoro.

Arsyad, L. (1999). Pengantar Perencanaan dan Pembangunan Ekonomi Daerah, Edisi Pertama, BPFE, Yogyakarta.

Benarkah Bumi Dipasena Hanya Kolam Kosong dan Air Belaka. (2018). Republika Online. https://republika.co.id/berita/pfj74q45 3/benarkah-bumi-dipasena-hanyakolam-kosong-dan-air-belaka

Chofyan, I., U. Ruston \& A. Hariyanto. (2016). Upaya Mempertahankan Kabupaten Karawang Sebagai Lumbung Padi Nasional. ETHOS Jurnal Penelitian dan Pengabdian Kepada Masyarakat. Vol 4 No.1.

Dari Titik Nol Dipasena. (2017). TEMPO. https://majalah.tempo.co/read/laporan -utama/153070/dari-titik-noldipasena\#

Dipasena Riwayatmu Kini. (2014). GresNews. http://www.gresnews.com/berita/huk um/84500-dipasena-riwayatmu-kini/

Gabrillin, A. (2018). Petambak Udang Dipasena Merasa Diperas Perusahaan Milik Sjamsul Nursalim. Kompas. https://sains.kompas.com/read/2018/0 7/26/17543191/petambak-udangdipasena-merasa-diperas-perusahaan- milik-sjamsul-nursalim

Hansen, K. (2018). 30 Stunning Abandoned Towns Around the World. Architectural Digest. https://www.architecturaldigest.com/ gallery/most-stunning-abandonedtowns-around-world

Rahman, Y.A \& A.L. Chamelia. (2015). Faktor-Faktor Yang Mempengaruhi PDRB Kabupaten/Kota Jawa Tengah. JEJAK. Journal of Economics \& Policy. ISSN 1979-715X.

Ricket, Oscar.(2020). Sejarah Berbagai Lokasi Diharap Jadi Surga di Bumi Tapi Akhirnya Gagal. https://www.vice.com/id/article/ne97 3k/sejarah-berbagai-lokasi-diharapjadi-surga-di-bumi-tapi-akhirnyagagal.

Saberan, H. (2002). Produk Domestik Regional Bruto. Rajawali,Jakarta

Setyawan, F. A. (2017). KPK: Suami Ayin Bangun Tambak Dipasena Milik Sjamsul Nursalim. CNNIndonesia. https://www.cnnindonesia.com/nasio nal/20170601032647-12-218663/kpksuami-ayin-bangun-tambak-dipasenamilik-sjamsul-nursalim

Sirojuzilam, (2008). Disparitas Ekonomi dan Perencanaan Regional, Ketimpangan Ekonomi Wilayah Barat dan Wilayah Timur Provinsi SumateraUtara. Pustaka Bangsa Press.

Sukirno, Sadono. (2006). Makro Ekonomi Teori Pengantar. Jakarta. Raja Grafindo Persada.

Todaro, M.P. (2006). Economic Development. Seventh Edition, New York, Addition Wesley Longman, Inc.

Untoro, Joko. (2010). Ekonomi Makro. Jakarta. Kawah Media Untoro, Jakarta.

Wandratie. (2014). Berdebar-Debar di Kota Hantu dan Situs Angker. https://www.cnnindonesia.com/gayahidup/20141030082242-269- 
8821/berdebar-debar-di-kota-hantu-

dan-situs-angker

Zakaria, T. Zulham dan Edy Gunawan.

(2018). Analisis Struktur Eknonomi

Kabupaten Aceh Besar. Jurnal

Perspektif Ekonomi Darussalam.

Volume 4Nomor 1, Maret 2018ISSN.

$2502-6976$ 